Research article

\title{
Isolation and characterization of nitrogen fixing bacteria that nodulate alien invasive plant species Prosopis juliflora (Swart) DC. in Marigat, Kenya
}

\author{
John O. Otieno ${ }^{1,2} *$, David W. Odee ${ }^{1}$, Stephen F. Omondi ${ }^{1}$, \\ Charles Oduor $^{1}$ and Oliver Kiplagat ${ }^{2}$
}

\author{
${ }^{1}$ Kenya Forestry Research Institute, P.O. Box 20412-00200, Nairobi, Kenya \\ ${ }^{2}$ School of Agriculture and Biotechnology, University of Eldoret, P.O. Box 1125-30100, Eldoret, Kenya \\ *Corresponding Author: jochiengo@gmail.com \\ [Accepted: 22 April 2017]
}

\begin{abstract}
A total of 150 bacterial strains were isolated from the root nodules of Prosopis juliflora growing in soils collected from Marigat area of Kenya. Soil samples from representative colonized zones of Tortilis, Grass and Prosopis were used in trapping the microsymbionts. A physiological plate screening allowed the selection of 60 strains which were characterized based on morphological, cultural and biochemical characteristics. Tolerance to salinity, acid and alkaline $\mathrm{pH}$ and resistance to antibiotics were studied as phenotypic markers. Morphological characteristics allowed the description of a wide physiological diversity among tested isolates. Establishing mutualistic interactions in novel environments is important for the successful establishment of some non-native plant species. The associations may have negative impact on the interaction networks of the native species whereby non-native species becoming dominant. Our study suggests that $P$. juliflora may have led to the diversity of $\mathrm{N}$-fixing microsymbionts observed in the study area. The study provides basis for further research on the phylogeny of rhozobial strains nodulating $P$. juliflora, as well as their use as inoculants to improve growth and nitrogen fixation in arid lands of Kenya. The data obtained in this study can be used for strain improvement and cross-inoculation experiments with different species when searching for well adapted and compatible partners.
\end{abstract}

Keywords: Prosopis juliflora - Rhizobia - Microsymbionts - Diversity.

[Cite as: Otieno JO, Odee DW, Omondi SF, Oduor C \& Kiplagat O (2017) Isolation and characterization of nitrogen fixing bacteria that nodulate alien invasive plant species Prosopis juliflora (Swart) DC. in Marigat, Kenya. Tropical Plant Research 4(1): 183-191]

\section{INTRODUCTION}

Prosopis juliflora (Sw.) DC is an evergreen shrub but sometimes grows into a small tree in the family Fabaceae, sub-family Mimosaidea (Polhill et al. 1981). The species is native to South America, Central America and the Caribbean (Pasiecznik et al. 2001). In the United States, it is well known as mesquite. It is fast growing, nitrogen-fixing and tolerant to arid conditions and saline soils (El-Keblawy \& Al-Rawai 2007). It is fast growing, nitrogen-fixing and tolerant to arid conditions and saline soils. The family leguminosae comprises approximately 650 genera, 1800 species and is the largest family of flowering plants (Polhill et al. 1981). Its species have worldwide distribution, are adverse, survive in a wide climatic condition and have a multiplicity of use. The leguminosae is divided into three sub families; Caesalpinoidae, Mimosoidae and Papilionoidea. The greatest occurrence of nodulation, $97 \%$ is in the Papilionaidae compared to $90 \%$ in the Mimosoidae and only $23 \%$ in the Caesalpinidae (Faria et al. 1989).

The current taxonomy has revealed a wide diversity of microsymbionts that can form $\mathrm{N}_{2}$-fixing symbioses with legume roots in a manner that is similar to rhizobia at the genus, species and intra species level. Traditionally, rhizobia were exclusively members of the Rhizobiaceae family in the Alphaproteobacteria class of bacteria, which includes the genera Allorhizobium, Azorhizobium, Bradyrhizobium Mesorhizobium, Rhizobium and Sinorhizobium (Sprent 2008). The term rhizobia have been used for all the bacteria that can 
produce nodules and fix atmospheric nitrogen in legumes (Brewin 2004, Cheng 2008). Rhizobia are bacteria capable of entering their legume hosts through root hairs, sites of lateral root emergence, or directly through root epidermis (Sprent et al. 2013), where they can induce the development of nodules where biological nitrogen fixation takes place (Gage 2004). The formation of root nodules involves complex molecular signaling pathways between legumes and rhizobia (Stacey 2007). Within root nodules, organic forms of reduced atmospheric nitrogen produced by the bacteria are utilized by the host plant and ultimately enter the earth's food webs. In exchange, bacterial symbionts acquire carbohydrates from legumes. Surprisingly, rhizobia are not monophyletic and represent a diverse array of bacteria found in both the Alphaproteobacteria ('alpha rhizobia', e.g. genera Rhizobium and Bradyrhizobium) and Betaproteobacteria ('beta rhizobia', e.g. genera Burkholderia and Cupriavidus) classes (Gyaneshwar et al. 2011). This symbiosis plays a very important role in agriculture as it can relieve the requirements for nitrogenous fertilizers during the growth of leguminous crops. However, relatively little information is available regarding microsymbionts species associated with $P$. juliflora an emerging alien invasive plant species in Kenya.

Invasive species are now considered as the second most important cause of the reduction in biodiversity in the world, after habitat loss. Loss of species biodiversity of the soil biota may be an acceptable consequence of the development and maintenance of agricultural systems. Habitat destruction at best erodes genetic diversity of the legume host and at worst leads to extinction, the subsequent fate of the rhizobial flora, through time, would be similar. A rich diversity of rhizobial species has been found in the tropics (Dreyfus et al. 1988, Odee et al. 1997). The need for conservation of both legume and host is therefore, paramount. There are numerous instances of woody legume introductions becoming weedy resulting (in some cases) in the need for expensive control programs. In particular, P. juliflora and Leucaena leucocephala have become noxious weeds in exotic environments (Fagg \& Stewart 1994). Of the 45 species of Prosopis described by Allen \& Allen (1981), 12 showed nodules, the efficiency of which varies among the species and among varieties within a species. Rhizobium strain isolated from P. juliflora nodualted peanut plants and was classified as belonging to the cowpea group (Subba Rao et al. 1982); the same occurred for rhizobium isolated from 5 species of the genera Acacia and Albizzia (Basak \& Goyal 1975). P. juliflora nodules have apical meristem, with indeterminate growth, thus with standing harsher stress condition provoked by temperature, drought and salinity, than species with globose nodules (Felker \& Clark 1980). Invasive trees in the Australian legume genus Acacia Mill. sensu stricto (Leguminosae subfam. Mimosoideae, formerly Acacia subgen. Phyllodineae DC; Maslin (2008), have received much research attention because of their invasion success and severe impacts on native ecosystems globally (Richardson et al. 2011). Acacias are known to form successful rhizobial interactions in their introduced ranges (Birnbaum et al. 2012, Wandrag et al. 2013) and have, in some instances, been co-introduced with their rhizobia (Crisóstomo et al. 2013, Ndlovu et al. 2013).

The unique partnership between legumes and rhizobia has been suggested as a major contributing factor to the success of some legumes as prominent invasive species in many parts of the world (Parker 2001) and that the ability to find 'compatible' rhizobia in introduced regions plays an important role in establishment success of legumes (Rodríguez-Echeverría et al. 2011). Variation in colonizing ability may be related to opportunities for symbionts acquisition from legume taxa that are indigenous to the invaded habitat (Richardson et al. 2000, Parker 2001). However, due to the variously restricted host ranges of rhizobia (Parker et al. 2004) only a subset of native legume taxa are likely to be potential sources of symbionts for any particular invasive legume. Most invaders will therefore encounter high spatial variability in symbionts availability owing to the heterogeneous distribution of native legumes across the landscape.

Under the right conditions, $P$. juliflora can produce a variety of valuable goods and services: construction materials, charcoal, soil conservation and rehabilitation of degraded and saline soils. Concern about deforestation, desertification and fuel wood shortages in the late 1970s and early 1980s prompted a wave of projects that introduced $P$. juliflora and other hardy tree species to new environments across the world. $P$. juliflora has survived where other tree species have failed and in many cases become a major nuisance. In 2004 it was rated one of the world's top 100 least wanted species (IUCN 2009). P. juliflora has invaded and continues to invade, millions of hectares of rangeland in South Africa, East Africa, Australia and coastal Asia (Pasiecznik et al. 2001). The tree species plays a leading role in the afforestation of arid lands. Their capability of growing on degraded land under arid conditions has made them especially suitable for this purpose. In general, mutualisms between invasive plants and rhizobia have been shown to increase plant biomass and to improve establishment success (Weir et al. 2004).

www.tropicalplantresearch.com 


\section{MATERIALS AND METHODS}

Host Plant and Soil sampling

Soil samples in this study were collected from three zones within the experimental site. In each zone, soil samples were taken from six random sampling points, at a depth of $15-30 \mathrm{~cm}$. The soil samples were pooled into a single sample and transferred to the laboratory for analysis and trapping experiment in the green house at KEFRI Muguga as described by Odee et al. (1997). Each soil was collected with aseptic precautions to avoid cross-contamination between soils from different zones. The soils were analyzed using the methods described in Anderson \& Ingram (1989). The $\mathrm{pH}$ was measured in calcium chloride $\mathrm{CaCl}_{2}$ ) as follows: $10 \mathrm{~g}$ of soil was suspended in $20 \mathrm{~cm}^{-3}$ of $10 \mathrm{~mol} . \mathrm{m}^{-3} \mathrm{Cacl}_{2}$ solution and measured using a Corning $240 \mathrm{pH}$ meter.

Seeds of $P$. juliflora were obtained from Kenya Forestry seed Center Muguga. The seeds of uniform size were selected and nipped using a blade and surface sterilized by immersion in $90 \%$ alcohol for 30 s, followed by $3 \%$ sodium hypochlorite $(\mathrm{NaOCl})$ solution for $3 \mathrm{~min}$ and rinsing several times in sterile water. Seeds were then germinated on $1 \%$ water agar plates and incubated at $26^{\circ} \mathrm{C}$ (Vincent 1970). The experiment was established in a greenhouse with temperature ranging from $19^{\circ} \mathrm{C}$ to $30^{\circ} \mathrm{C}$, using complete randomized blocks design (CRBD) with 10 replications, in PVC pots. Four seeds were planted which were later thinned out to two per pot. The tree plants were then harvested after 90 days.

\section{Nodulation Assessment and Rhizobial Isolation}

The plants were cut at the level of the growth media to separate the shoot and the root. Shoot height was recorded in centimeters using a meter ruler. Nodules were detached from the root, counted and fresh weight also recorded at the same time. The different plant parts were then put in brown paper bags and then oven dried at $60^{\circ} \mathrm{C}$ for 2 days. The dry weights in $\mathrm{mg}$ of the plants were then taken separately using an electronic weighing balance. Ten nodules were picked per pot giving a total of 100 nodules per trap host per zone. Fifty of those nodules were selected at randomly for isolation and the rest were kept in McCartney bottles containing silica gel. Fresh nodules were transferred into $95 \%$ ethanol for 5-10 s and then in $1 \% \mathrm{NaOCl}$ for 6 min. Each nodule was then successively rinsed in sterile distilled water (at least 6 changes) to remove traces of the sterilant, each time sterilizing the forceps by dipping it into $95 \%$ alcohol followed by flaming with Bunsen burner. The surface sterilized nodule was then placed in a drop of sterile petri-dish and then crushed with a blunt tipped forceps. A loopful of the crushed nodule was then picked and streaked across the surface of yeast extract mannitol agar (YMA) plates. The composition of YMA was according to Vincent (1970). The streaked plates were incubated at $28^{\circ} \mathrm{C}$ until colonies appeared. Different types of isolates were re-isolated on diagnostic YMA media before being transferred to YMA. The isolates were then stored at $-70^{\circ} \mathrm{C}$ for further work.

\section{Intrinsic antibiotic resistance (IAR)}

Stock solution of the following antibiotic were prepared; Ampicillin (Sigma) $20 \mu \mathrm{g} . \mathrm{ml}^{-1}$, Streptomycin (Sigma) $200 \mu \mathrm{g} \cdot \mathrm{ml}^{-1}$, Kanamycin (Sigma) $100 \mu \mathrm{g} \cdot \mathrm{ml}^{-1}$, Tetracycline (Sigma) $50 \mu \mathrm{gml}^{-1}$ Rifamycin (Sigma) 50 $\mu \mathrm{g} . \mathrm{ml}^{-1}$, Nalicidixic acid (Sigma) $20 \mu \mathrm{g} \cdot \mathrm{ml}^{-1}$. The solutions were filter-sterilized using 0.22 micro ml Millipore filters and stored in one use aliquots at $-20^{\circ} \mathrm{C}$ at each agar plate preparation, an aliquot of each antibiotic was thawed at room temperature and added aseptically to freshly prepared sterile molten YEMA (Yeast extract and Agar from Difco Labaoratories) at $50^{\circ} \mathrm{C}$ to $60^{\circ} \mathrm{C}$ according to Vincent (1970) to give the desired final concentration. Rhizobial isolates were grown in yeast Manitol broth to late exponential phase and diluted accordingly before being used to inoculate the agar plates with a Denley multipoint inoculator. There were two replicates for each antibiotic concentration combination. Growth on antibiotic plates was compared with control (antibiotic free) plates and scored as follows, (+) good growth same as control, (+/-) growth less or weak than control and (-) no growth.

\section{Salt and $\mathrm{pH}$ tolerance level determination}

The level of tolerance to sodium chloride $(\mathrm{NaCl})$ was determined on YMA plates containing the following levels of $\mathrm{NaCl}$ concentration in mol. $\mathrm{m}^{-3} ; 0,2,4,6,9,10$. Rhizobia isolates were grown and inoculated as for IAR. Growth was compared with YMA plates with the normal concentration and scored as follows, (+) good growth same as control, (+/-) growth less or weak than control and (-) no growth. The same was done for $\mathrm{pH}$ tolerance level determination.

\section{Statistical analysis}

The data obtained from the ten replicates were subjected to statistical analysis by using Genstat version 12.0 
computer program. Morphological characterization data was converted into an absence/presence binary matrix $(0,1)$ using the method described by (Rohlf 1993).

\section{RESULTS AND DISCUSSION Soil analysis}

The soil $\mathrm{pH}$ of the zones varied from 7.48 Tortilis zone, 7.56 Prosopis zone and 8.32 Grass zone in water. In $\mathrm{CaCl}^{2}$ soil $\mathrm{pH}$ varied from 6.85 Tortilis zone, 7.08 Prosopis zone and 7.41 Grass zone in. Electrical conductivity ranged from $0.043 \mathrm{mS} . \mathrm{cm}-1$ Tortilis zone, $0.053 \mathrm{mS} . \mathrm{cm}^{-1}$ Prosopis zone and $0.064 \mathrm{mS}^{-\mathrm{cm}^{-1}} \mathrm{Grass}$ zone. Available ammonia varied from 1.78 ppm Grass zone, 2.37 ppm Prosopis zone and 2.11 ppm Tortilis zone. Available nitrates varied from $1.12 \mathrm{ppm}$ Grass zone, $2.21 \mathrm{ppm}$ Prosopis zone and 1.18 ppm Acacia zone.

\section{Height, fresh, nodulation and dry weight determination}

Tortilis zone showed significance difference in terms of plants height compared to the other zones. Prosopis zone was the best in terms of nodulation. The other two zones did not show significance difference in terms of nodulation. In terms of nodule fresh weight, Prosopis zone had higher significant difference compared to the other two zones which did not show significance difference. Dry shoot matter was highest in Prosopis zone and Acacia zone but there was no significance difference. Grass zone was poor in terms of shoot dry matter compared to the other two zones.

\section{Isolation and Identification of Microsymbionts}

A total of 150 microsymbionts were successfully isolated from the root nodules of the host plants. The isolates were differentiated by their growth rate into either fast-growing (3 days) or slow-growing 5 days. Most of the fast growing bacteria were observed as acid producers, while the slow growers were alkaline producers based on the changes of $\mathrm{pH}$ in YEMA incorporated with BTB. Most of the strains failed to absorb the red colour from Congo red.

\section{Physiological characteristic}

Table 1. Differentiating physiological traits of the rhizobial isolates recovered from Prosopis juliflora using soil collected from grass zone (GZPJ).

\begin{tabular}{|c|c|c|c|c|c|c|c|c|c|c|c|c|c|c|c|c|c|}
\hline \multirow{2}{*}{ Isolate } & \multicolumn{5}{|c|}{ pH tolerance } & \multicolumn{6}{|c|}{ NaCl tolerance $(\%)$} & \multicolumn{6}{|c|}{ Intrinsic antibiotic resistance (IAR) } \\
\hline & 4 & 6 & 8 & 9 & $\mathbf{1 0}$ & $\mathbf{0}$ & 1 & 2 & 3 & 4 & 5 & AMP & STR & KAN & RIF & TET & NAL \\
\hline GZPJ-1 & - & + & - & - & - & + & - & - & - & - & + & - & - & - & - & - & - \\
\hline GZPJ-2 & + & + & + & + & + & + & + & + & - & + & + & + & - & - & - & + & - \\
\hline GZPJ-3 & + & + & + & + & + & + & + & - & + & + & - & + & - & - & - & - & - \\
\hline GZPJ-4 & - & - & - & - & - & - & - & - & - & - & + & - & - & - & - & - & - \\
\hline GZPJ-5 & + & + & + & + & + & + & - & - & - & + & + & - & - & - & - & + & - \\
\hline GZPJ-6 & + & + & + & + & + & + & + & + & + & + & - & - & - & - & + & - & - \\
\hline GZPJ-7 & - & + & + & + & + & + & + & - & + & + & + & + & - & - & - & - & - \\
\hline GZPJ-8 & + & + & + & + & + & + & + & + & + & + & + & + & + & - & - & + & - \\
\hline GZPJ-9 & - & + & + & + & + & + & + & - & - & + & + & + & - & - & - & - & - \\
\hline GZPJ-10 & + & + & + & + & + & + & + & + & + & + & + & + & + & - & - & + & - \\
\hline GZPJ-11 & + & + & + & + & + & + & + & + & + & + & + & + & - & - & + & + & - \\
\hline GZPJ-12 & + & + & + & + & + & + & + & + & + & + & + & + & - & - & + & + & - \\
\hline GZPJ-13 & + & + & + & + & + & + & + & + & + & + & + & - & - & - & - & + & - \\
\hline GZPJ-14 & + & + & + & + & + & + & + & + & + & + & + & - & - & - & - & + & - \\
\hline GZPJ-15 & + & + & + & + & + & + & + & + & + & + & + & - & - & - & - & + & - \\
\hline GZPJ-16 & + & + & + & + & + & + & + & - & + & + & + & - & - & - & - & + & - \\
\hline GZPJ-17 & + & + & + & + & + & + & + & - & - & + & - & - & - & - & - & + & - \\
\hline GZPJ-18 & + & + & + & + & + & + & + & - & - & + & - & + & - & - & - & + & - \\
\hline GZPJ-19 & + & + & + & + & + & + & + & + & + & + & + & + & + & - & - & + & - \\
\hline GZPJ-20 & - & + & + & + & + & + & + & - & - & + & - & + & - & - & - & - & - \\
\hline
\end{tabular}

Note:,+- , strains were positive and negative, respectively.

As shown in tables (1-3), the isolates tested showed a wide diversity in their $\mathrm{pH}$ tolerance. From $90 \%$ to $100 \%$ of the isolates grew in lightly acid and neutral $\mathrm{pH}$. A few of the isolates were unable to withstand either very low or very high $\mathrm{pH}$ across the zones. Prosopis zone had over $60 \%$ isolates susceptible to $\mathrm{pH} 4$. Over $70 \%$ of the isolates grew well in $\mathrm{pH} 6$ showing a neutral and base-tolerant tendency. This tendency might be related to the basic $\mathrm{pH}$ that characterizes most of the origin soil from which the isolates were recovered. As shown in 
(Table 2), the isolates exhibited a wide diversity in their salt tolerance. The salt inhibitory concentration varied among strains. There was tolerance to low salt levels but the percentage of tolerant strains decreased rapidly and only a few of the strains showed moderate growth at $\mathrm{pH}$. All the isolates performed well across the zones in

Table 2. Differentiating physiological traits of the rhizobial isolates recovered from Prosopis juliflora using soil collected from tortilis zone (TZPJ).

\begin{tabular}{|c|c|c|c|c|c|c|c|c|c|c|c|c|c|c|c|c|c|}
\hline \multirow{2}{*}{ Isolate } & \multicolumn{5}{|c|}{ pH tolerance } & \multicolumn{6}{|c|}{ NaCl tolerance $(\%)$} & \multicolumn{6}{|c|}{ Intrinsic antibiotic resistance (IAR) } \\
\hline & 4 & 6 & 8 & 9 & 10 & $\mathbf{0}$ & 1 & 2 & 3 & 4 & 5 & AMP & STR & KAN & RIF & TET & NAL \\
\hline TZPJ-1 & - & + & + & + & + & + & + & + & + & + & + & + & - & - & + & + & - \\
\hline TZPJ-2 & + & + & + & + & + & + & + & + & + & + & + & + & - & - & + & + & - \\
\hline TZPJ-3 & - & - & - & - & - & - & - & - & - & - & - & - & - & - & - & - & - \\
\hline TZPJ-4 & - & + & + & + & + & + & + & + & + & + & + & - & - & - & - & + & - \\
\hline TZPJ-5 & + & + & + & + & + & + & + & + & + & + & + & + & - & - & - & + & - \\
\hline TZPJ-6 & - & + & + & - & + & + & - & - & - & - & - & - & - & - & - & - & - \\
\hline TZPJ-7 & - & + & + & + & + & + & + & + & + & + & + & + & + & + & + & + & + \\
\hline TZPJ-8 & + & + & + & + & + & + & + & + & + & + & + & + & - & - & + & + & - \\
\hline TZPJ-9 & - & + & + & + & + & + & + & - & - & + & + & + & - & - & - & + & - \\
\hline TZPJ-10 & - & + & + & + & + & + & + & - & - & + & + & - & - & - & - & + & - \\
\hline TZPJ-11 & + & + & + & + & + & + & + & + & + & + & + & + & - & - & - & + & - \\
\hline TZPJ-12 & + & + & + & + & + & + & + & - & - & - & + & - & - & - & - & + & - \\
\hline TZPJ-13 & + & + & + & + & + & + & + & + & + & + & + & + & - & - & + & + & - \\
\hline TZPJ-14 & + & + & + & + & + & + & + & + & + & + & + & - & - & - & - & + & - \\
\hline TZPJ-15 & - & + & + & + & + & + & + & - & + & + & + & - & - & - & - & + & - \\
\hline TZPJ-16 & - & + & + & + & + & + & + & - & - & + & + & - & - & - & - & - & - \\
\hline TZPJ-17 & - & + & + & + & + & + & - & - & - & - & - & - & - & - & - & - & - \\
\hline TZPJ-18 & - & + & + & - & - & - & - & - & - & - & - & - & - & - & - & - & - \\
\hline TZPJ-19 & - & + & + & + & + & + & + & + & + & + & + & - & - & - & - & + & - \\
\hline TZPJ-20 & - & + & + & + & + & + & - & - & - & - & - & - & - & - & - & - & - \\
\hline
\end{tabular}

Note:,+- , strains were positive and negative, respectively.

Table 3. Differentiating physiological traits of the rhizobial isolates recovered from Prosopis juliflora using soil collected from prosopis zone (PZPJ).

\begin{tabular}{|c|c|c|c|c|c|c|c|c|c|c|c|c|c|c|c|c|c|}
\hline \multirow{2}{*}{ Isolate } & \multicolumn{5}{|c|}{ pH tolerance } & \multicolumn{6}{|c|}{ NaCl tolerance $(\%)$} & \multicolumn{6}{|c|}{ Intrinsic antibiotic resistance (IAR) } \\
\hline & 4 & 6 & 8 & 9 & 10 & $\mathbf{0}$ & 1 & 2 & 3 & 4 & 5 & AMP & STR & KAN & RIF & TET & NAL \\
\hline PZPJ-1 & + & + & + & + & - & + & + & + & + & + & + & + & + & + & + & + & + \\
\hline PZPJ-2 & + & + & + & + & + & + & + & + & + & + & + & + & + & + & + & + & + \\
\hline PZPJ-3 & + & + & + & + & + & + & + & + & + & + & + & + & + & + & + & + & + \\
\hline PZPJ-4 & + & - & + & + & - & - & + & + & + & + & + & + & + & + & + & + & + \\
\hline PZPJ-5 & + & + & + & + & + & + & + & + & + & + & + & - & - & - & - & - & - \\
\hline PZPJ-6 & + & + & + & + & + & + & - & - & - & - & - & - & - & - & - & - & - \\
\hline PZPJ-7 & + & + & + & + & + & + & + & - & - & + & + & - & - & - & - & - & - \\
\hline PZPJ-8 & - & + & + & + & + & + & + & - & - & + & - & - & + & - & - & + & - \\
\hline PZPJ-9 & - & + & + & + & + & + & + & + & + & + & + & - & - & - & + & - & - \\
\hline PZPJ-10 & - & - & + & + & - & - & - & - & - & - & - & - & - & - & - & - & - \\
\hline PZPJ-11 & - & + & + & + & + & + & + & + & + & + & + & + & - & + & - & - & + \\
\hline PZPJ-12 & - & + & + & + & + & + & + & - & - & - & - & - & - & - & - & - & - \\
\hline PZPJ-13 & - & + & + & + & + & + & + & - & - & + & + & + & - & - & - & - & - \\
\hline PZPJ-14 & - & + & + & + & + & + & + & - & - & - & - & - & - & - & - & + & - \\
\hline PZPJ-15 & + & + & + & + & + & + & + & + & + & + & + & + & - & - & + & + & - \\
\hline PZPJ-16 & - & + & + & + & - & - & + & - & - & - & - & - & - & - & - & + & - \\
\hline PZPJ-17 & + & + & + & + & + & + & + & + & - & + & + & + & - & + & - & - & - \\
\hline PZPJ-18 & + & + & + & + & + & + & + & - & - & - & - & - & - & - & - & + & - \\
\hline PZPJ-19 & - & + & + & + & + & + & + & - & - & + & + & + & - & - & - & + & - \\
\hline PZPJ-20 & + & + & + & + & + & + & + & + & + & + & + & + & + & + & + & + & - \\
\hline
\end{tabular}

Note:,,+- strains were positive and negative, respectively

terms of tolerance to salt. This result confirms a selection pressure for tolerance to salinity. The evaluation of intrinsic resistance to antibiotics (IAR) showed that most of the isolates (67\%) exhibited high resistance to tetracycline $\left(50 \mu \mathrm{g} \cdot \mathrm{ml}^{-1}\right)$ and $(50 \%)$ to ampicillin $\left(20 \mu \mathrm{g} \cdot \mathrm{ml}^{-1}\right)$ table 3 . In the presence of nalidixic acid (20 $\left.\mu \mathrm{g} \cdot \mathrm{ml}^{-1}\right)$ kanamycin $\left(100 \mu \mathrm{g} \cdot \mathrm{ml}^{-1}\right)$, rifamycin $\left(50 \mu \mathrm{g} \cdot \mathrm{ml}^{-1}\right)$ and streptomycin $\left(200 \mu \mathrm{g} \cdot \mathrm{ml}^{-1}\right)$, only $10 \%$ to $40 \%$ of 
the isolates were resistant. All isolates from Grass zone were susceptible to nalidixic acid $\left(20 \mu \mathrm{g} . \mathrm{ml}^{-1}\right)$ and kanamycin $\left(100 \mu \mathrm{g} . \mathrm{ml}^{-1}\right)$ except a few which were isolated from Prosopis zone and Tortilis zone (Table 3). In terms of zones Prosopis had the highest number $(38 \%)$ of strains which showed resistance to most of the antibiotics followed by Tortilis zone (23\%) and Grass zone was (18\%). Cluster analysis grouped the 60 strains by genomic similarity and resulted in the dendrogram as shown in (Figs. 1-3). The dendrogram are further divided into sub-clusters of 6 in the Prosopis zone, 5 in Tortilis zone and 5 in grass zone and some isolates without any grouping thus indicating that these isolates are probably unique and can be identified based on 16SrRNA gene sequencing technique.

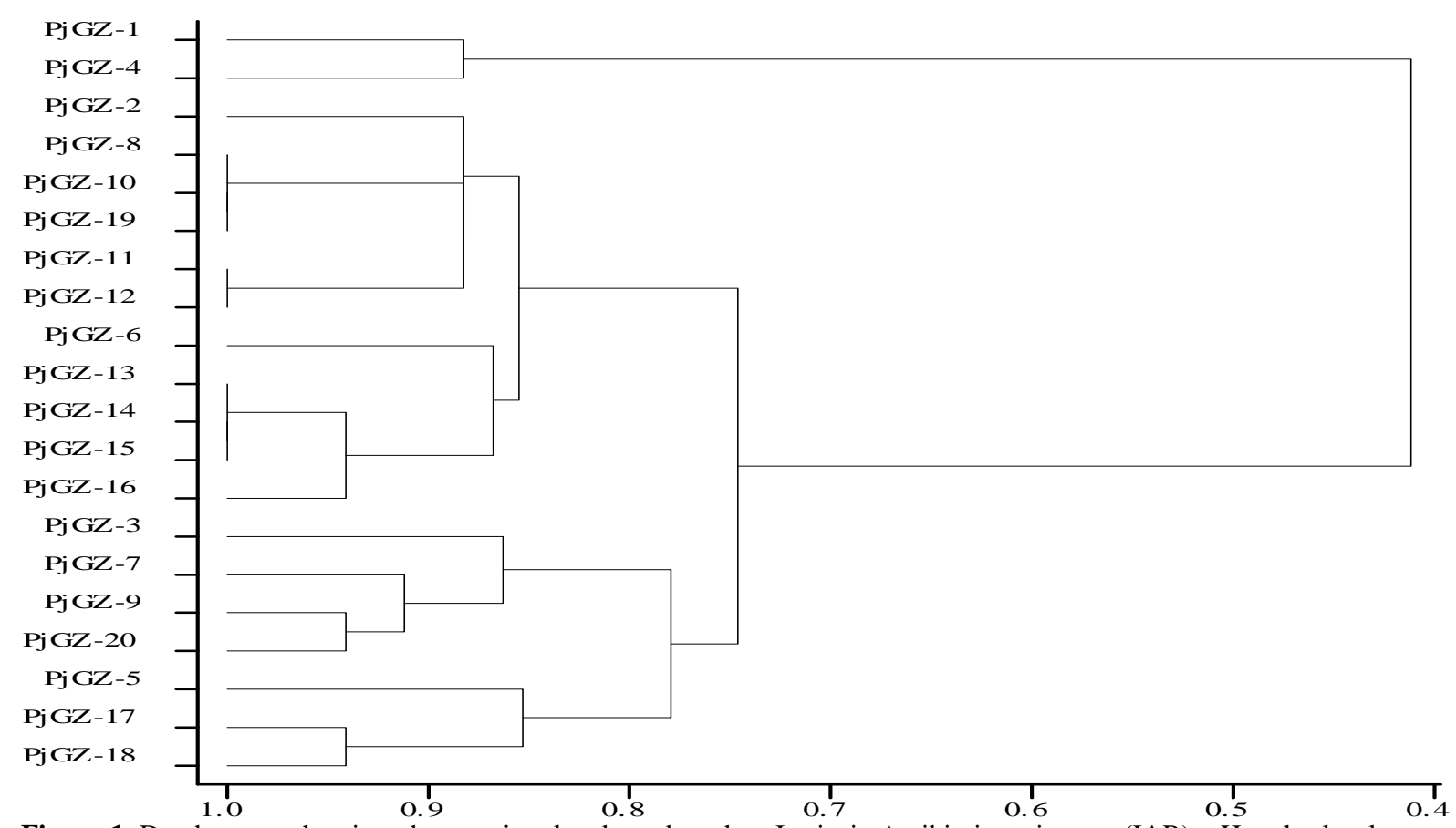

Figure 1. Dendrogram showing phenotypic relatedness based on Intrinsic Antibiotic resistance (IAR), $\mathrm{pH}$ and salt tolerance among 20 rhizobial isolates from Grass zone (PjGZ). [Cluster analysis was performed using the Unweighted Paired Group with Arithmetic Average (UPGMA)]

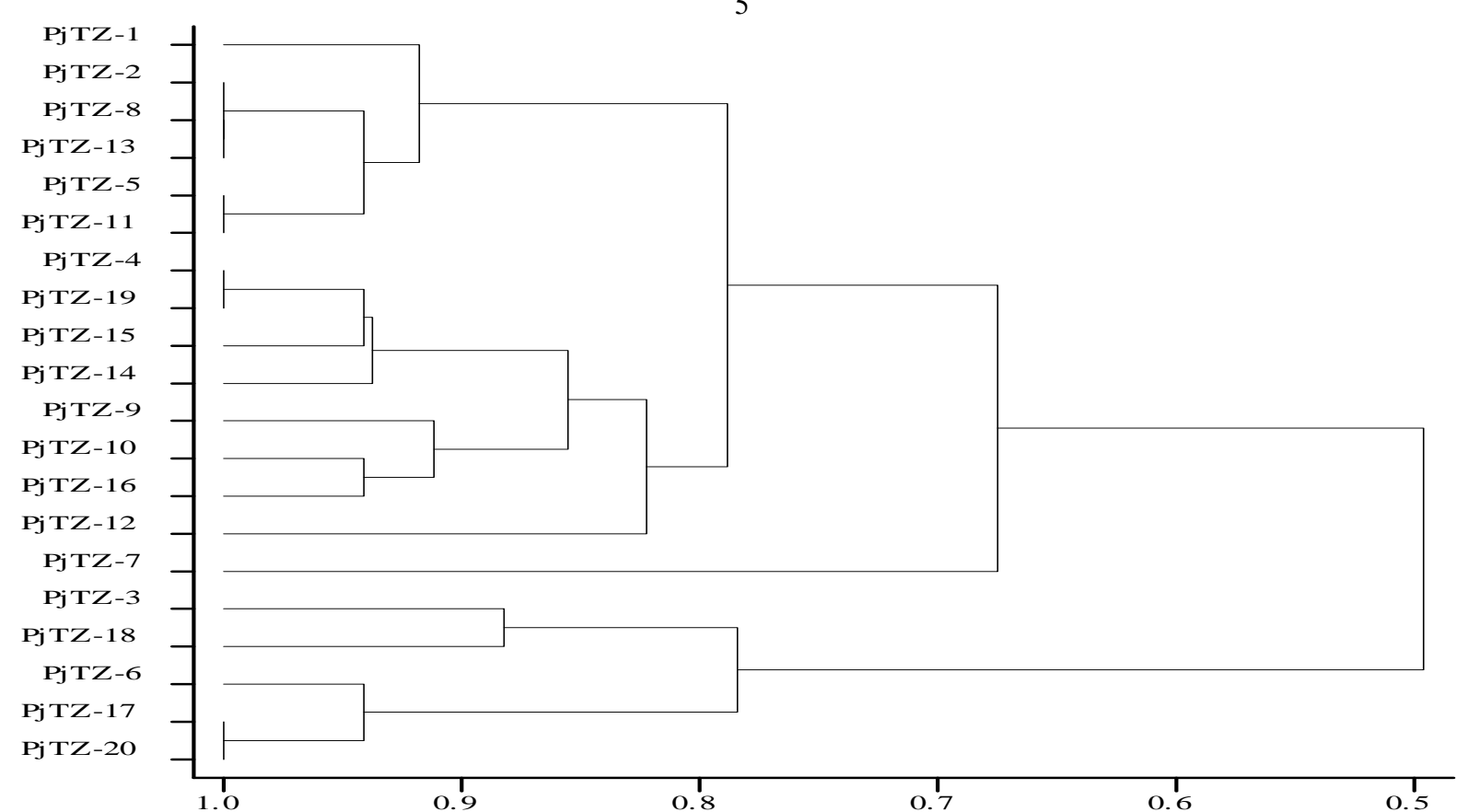

Figure 2. Dendrogram showing phenotypic relatedness based on Intrinsic Antibiotic resistance (IAR), $\mathrm{pH}$ and salt tolerance among 20 rhizobial isolates from Tortilis zone (PjTZ). [Cluster analysis was performed using the Unweighted Paired Group with Arithmetic Average (UPGMA)] 


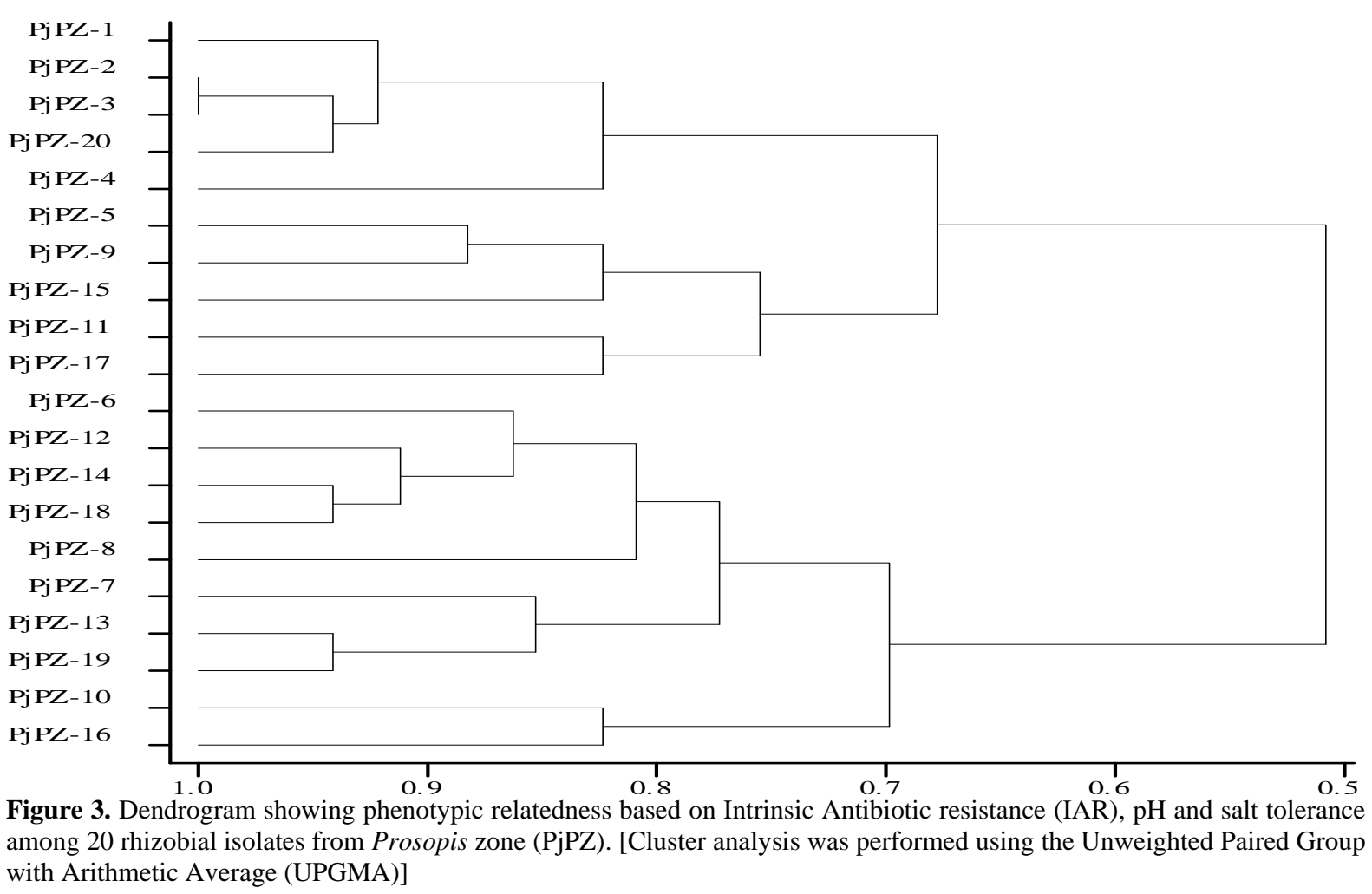

\section{CONCLUSION}

Our findings indicate that, like many other plant-mutualism interactions, native legume rhizobium interactions are impacted by the presence of invasive species in communities. This study, therefore, provides the basis for further research on the phylogeny of rhizobium strains nodulating Prosopis juliflora as well as their use as inoculants to improve growth and nitrogen fixation in arid lands. Since no inoculation studies have been carried out to experimentally measure the extent to which invasive legumes may be symbionts limited in different sites within their natural range. Continued efforts should be made to understand the complex association between the invasive plant species and the symbiotic partners and ultimately to employ efficient strains in the sustainable agricultural practice.

\section{ACKNOWLEDGEMENTS}

The authors wish to thank the Director, Kenya Forestry Research Institute, for providing the infrastructure facilities and support. This work was supported by funds from EU Marie Curie fellowsip Contract MIIFR-CT2006-980056. Technical assistance of James Were of KEFRI Biotechnology laboratory in conducting the experiments is duly acknowledged.

\section{REFERENCE}

Allen ON \& Allen EK (1981) The leguminosae: A source of characteristics, uses, and nodulation. The University of Wisconsin Press, Madison, $812 \mathrm{p}$.

Anderson JM \& Ingram JSI (1989) Tropical Soil Biology and Fertility: A handbook of methods of analysis. CAB International, Wallingford, UK.

Basak MK \& Goyal SK (1975) Studies on tree legumes. I. Nodulation pattern and characterization of the symbiont. Annals of Arid Zone 14: 367-370.

Birnbaum C, Barrett LG, Thrall PH \& Leishman MR (2012) Mutualisms are not constraining cross-continental invasion success of Acacia species within Australia. Diversity and Distributions 18: 962-976.

Brewin NJ (2004) Plant cell wall remodeling in the Rhizobium-legume symbionts. CRC Critical Reviews in Plant Science 23: 293-326.

Cheng Q (2008) Perspectives in biological nitrogen fixation research. Journal of Integrative Plant Biology 50: 786-798.

Crisóstomo JA, Rodríguez-Echeverría S \& Freitas H (2013) Co-introduction of exotic rhizobia to the rhizosphere 
rhizosphere of the invasive legume Acacia saligna along an intercontinental gradient. Applied Soil Ecology 64: $118-126$.

Dreyfus B, Garcia JL \& Gillis M (1988) Characterization of Azorhizobium caulinodans gen. nov., sp. nov., a stem-nodulating nitrogen-fixing bacterium isolated from Sesbania rostrata. International Journal Systematic of Bacteriology 38: 89-98.

El-Keblawy A \& Al-Rawai A (2007) Impacts of the invasive exotic Prosopis juliflora (Sw.) D.C. on the native flora and soils of the UAE. Plant Ecology 190: 23-35.

Fagg CW \& Stewart JL (1994) The value of Acacia and Prosopis in arid and semiarid environments. Journal of Arid Environments 27: 3-25.

Faria SM, Lewis GP, Sprent JI \& Sutherland JM (1989) Occurrence of nodulation in the leguminosae. New Phytologist 111: 607-619.

Felker P \& Clark PR (1980) Nitrogen fixation (acetylene reduction) and cross inoculation in 12 Prosopis (mesquite) species Plant \& Soil 57: 177-186.

Gage DJ (2004) Infection and invasion of roots by symbiotic, nitrogen-fixing rhizobia during nodulation of temperate legumes. Microbiology and Molecular Biology Reviews 68: 280-300.

Gyaneshwar P, Hirsch AM, Moulin L, Chen W-M, Elliott GN, Bontemps C, Estrada-de Los Santos P, Gross E, Dos Reis FB, Sprent JI, Young JP \& James EK (2011) Legume-nodulating betaproteobacteria: diversity, host range and future prospects. Molecular Plant-Microbe Interactions 24: 1276-1288.

IUCN (2009) The 2009 IUCN Red List of Threatened Species. The World Conservation Union (IUCN), Switzerland.

Maslin BR (2008) Generic and subgeneric names in Acacia following retypification of the genus. Muelleria 26(1): 7-9.

Ndlovu J, Richardson DM, Wilson JRU \& Le Roux JJ (2013) Co-invasion of South African ecosystems by an Australian legume and its rhizobial symbionts. Journal of Biogeography 40: 1240-1251.

Odee DW, Sutherland JM, Makatiani ET, McInroy SG \& Sprent JI (1997) Phenotypic characteristics and composition of rhizobia associated with woody legumes growing in diverse Kenyan conditions. Plant and Soil 188: 65-75.

Parker MA (2001) Mutualism as a constraint on invasion success for legumes and rhizobia. Diversity and Distributions 7: 125-136.

Parker MA, Doyle JL \& Doyle JJ (2004) Comparative phylogeography of Amphicarpaea legumes and their root- nodule symbionts in Japan and North America. Journal of Biogeography 31: 425-434.

Pasiecznik NM, Felker P, Harris PJC, Harsh LN \& Cruz G (2001) The Prosopis juliflora - Prosopis pallida Complex: A Monograph. Coventry, UK: HDRA.

Pasiecznik NM, Tewari JC, Harsh LN, Felker P, Harris PJC, Cadoret K, Cruz G \& Maldonado LJ (2001) The Prosopis juliflora - Prosopis pallida complex: a monograph. Henry Doubleday Research Association (HDRA), Coventry, UK, 162 pp. [ISBN:0-905343-30-1]

Polhill RM, Raven PH \& Stirton CH (1981) Evolution and systematics of the Leguminosae. In Advances in legume systematics. Royal Botanic Gardens, Kew, pp. 1-26.

Richardson DM, Allsopp N, D’Antonio CM, Milton SJ \& Rejmanek M (2000) Plant invasions--the role of mutualisms. Biological Reviews of the Cambridge Philosophical Society 75(1): 65-93.

Richardson DM, Carruthers J, Hui C, Impson FAC, Robertson MP \& Rouget M (2011) Human-mediated introductions of Australian acacias- a global experiment in biogeography. Diversity and Distributions 17: 771-787.

Rodríguez-Echeverría S, Le Roux JJ, Crisóstomo JA \& Ndlovu J (2011) Jack-of-all-trades and master of many? How does associated rhizobial diversity influence the colonization success of Australian Acacia species? Diversity and Distributions 17: 946-957.

Rohlf FJ (1993) NTCYS-pc Numerical Taxonomy and Multivariate Analysis System. Version 1.80.

Sprent JI (2008) 60Ma of legume nodulation: What's new? What's changing? Journal of experimental Botany 59: $10881-1084$.

Sprent JI, Ardley JK \& James EK (2013) From North to South: a latitudinal look at legume nodulation processes. South African Journal of Botany 89: 31-41.

Stacey G (2007) The Rhizobium-legume nitrogen-fixing symbiosis In: Bothe H, Ferguson SJ \& Newton WE (eds) Biology of the Nitrogen Cycle. Elsevier Inc., Amsterdam, the Netherlands, pp. 147-163.

www.tropicalplantresearch.com 
Subba Rao NS, Sen AN \& Dadarwal KR (1982) Rhizobium research in India. In: Review of soil research in India, Part I. $12^{\text {th }}$ International congress of soil science held at Indian Society of Soil Science, New Delhi, pp. 211-224.

Vincent JM (1970) A manual for the practical study of root-nodule bacteria. In: International biological program handbook. Blackwell Scientific Publication, Oxford, UK.

Wandrag EM, Sheppard A, Duncan RP \& Hulme PE (2013) Reduced availability of rhizobia limits the performance but not invasiveness of introduced Acacia. Journal of Ecology 101: 1103-1113.

Weir BS, Turner SJ, Silvester WB, Park DC \& Young JM (2004) Unexpectedly diverse Mesorhizobium strains and Rhizobium leguminosarum nodulate native legume genera of New Zealand, while introduced legume weeds are nodulated by Bradyrhizobium species. Applied Environmental Microbiology 70: 5980-5987. 